Збірник наукових праць. Серія: Галузеве машинобудування, будівництво

Academic journal. Series: Industrial Machine Building, Civil Engineering

http://journals.pntu.edu.ua/znp

https://doi.org/10.26906/znp.2018.51.1310

UDC 621.926.5

\title{
Concrete pump working capacity determination in the composition of small-sized technological set equipment for the wet method gunite work
}

\author{
Emeljanova Inga ${ }^{1}$, Chayka Denys ${ }^{2}$, Bondar Viktor $^{3}$, Virchenko Viktor ${ }^{4 *}$ \\ ${ }^{1}$ Harkiv National University of Construction and Architecture https://orcid.org/0000-0002-8989-958X \\ ${ }^{2}$ Harkiv National University of Construction and Architecture https://orcid.org/0000-0001-8338-7105 \\ ${ }^{3}$ Harkiv National University of Construction and Architecture \\ ${ }^{4}$ Poltava National TechnicalYuri Kondratyuk University https://orcid.org/0000-0002-5346-9545 \\ *Corresponding author: virchenko.viktor@gmail.com
}

\begin{abstract}
The small-sized technological set equipment with a universal, non-porous hose concrete pump is shown, that is verified during the execution of wet method gunite work. Dependencies for determination of basic universal hose concrete pump work parameters are proposed. The stand surface concreted with wet-cracking method, by the using of the concrete mixture composition, which has been checked during the gunite work execution on the construction site. A check of the resulting rubberconcrete coating strength has been carried out. The stability of the offered technological package operating conditions is confirmed.
\end{abstract}

Keywords: small-sized technological set equipment, gunite work, universal hose concrete pump, gun concrete.

\section{Визначення працездатності бетононасоса у складі технологічного комплекту малогабаритного обладнання для проведення торкрет-робіт мокрим способом}

\author{
Смельянова І.А. ${ }^{1}$, Чайка Д.О. ${ }^{2}$, Бондар В.О. ${ }^{3}$, Вірченко В.В. ${ }^{4 *}$ \\ ${ }^{1}$ Харківський національний університет будівництва та архітектури \\ ${ }^{2}$ Харківський національний університет будівництва та архітектури \\ ${ }^{3}$ Харківський національний університет будівництва та архітектури \\ ${ }^{4}$ Полтавський національний технічний університет імені Юрія Кондратюка \\ *Адреса для листування: virchenko.viktor@gmail.com
}

\begin{abstract}
Запропоновано ряд технологічних комплектів малогабаритного обладнання для виконання торкрет-робіт мокрим способом, один 3 них наведено в цій статті. Показано технологічний комплект малогабаритного обладнання з універсальним безпоршневим шланговим бетононасосом, який використовується як базова машина такого комплекту. Запропоновано залежності для визначення основних параметрів роботи універсального шлангового бетононасоса: продуктивності, витрат потужності на транспортування бетонної суміші, тиску всмоктування суміші з бункера та тиску ії нагнітання до торкрет-сопла. Перевірено роботу шлангового бетононасоса в складі технологічного комплекту при виконанні торкрет-робіт мокрим способом. Забетоновану способом мокрого торкретування стендову поверхню 3 використанням складу бетонної суміші перевірено при виконанні торкрет-робіт на будівельному майданчику. Одержане торкрет-бетонне покриття після 28 діб твердіння в природних умовах було випробувано на міцність на стиск. За результатами проведених досліджень підтверджено стабільність умов роботи технологічного комплекту, що пропонується. Установлено, що новий універсальний безпоршневий шланговий бетононасос придатний для використання його у складі технологічного комплекту малогабаритного обладнання та виконання торкрет-робіт мокрим способом.
\end{abstract}

Ключові слова: технологічний комплект малогабаритного обладнання, торкретування, універсальний шланговий бетононасос, торкрет-бетон 
Formulation of the problem. In modern construction, monolithic concretization plays a central role. There are a lot of different equipment types used in these works for the concrete mixes preparation and transportation $[1,2]$.

Recent research analysis. The studies of these machines are represented in this works $[3,4]$.

Identification of previously unsettled parts of the general problem. Considered structures of machines, used in monolithic concreting, have disadvantages that relate to the prepared mixture quality and the operation reliability in comparison with the machines, offered in this work.

The experience of small-sized technological set equipment multiple use at various construction sites shows their efficiency and suggests that the wide-scale use of these machines is viable. The set content includes new machines and equipment, protected by the
Ukrainian patent. This includes concrete grout pumps of different design, concrete mixers operating in cascade mode and gunned nozzles with ring tips [5, 6].

Statement of assignment and methods of its solving. It is proposed to include a universal hose concrete pump, which is developed at the Department of the Mechanization of Construction Processes of the Kharkov National University of Construction and Architecture [7], in the small-sized technological set equipment.

Study results and their discussion. Possibility to carry out a gunite work wet process using a universal hose concrete pump has been investigated in the small-sized technological set equipment (Fig. 1) [8].

Small-sized technological set equipment in accordance with the basic scheme in Fig. 1 is shown in Fig. 2.

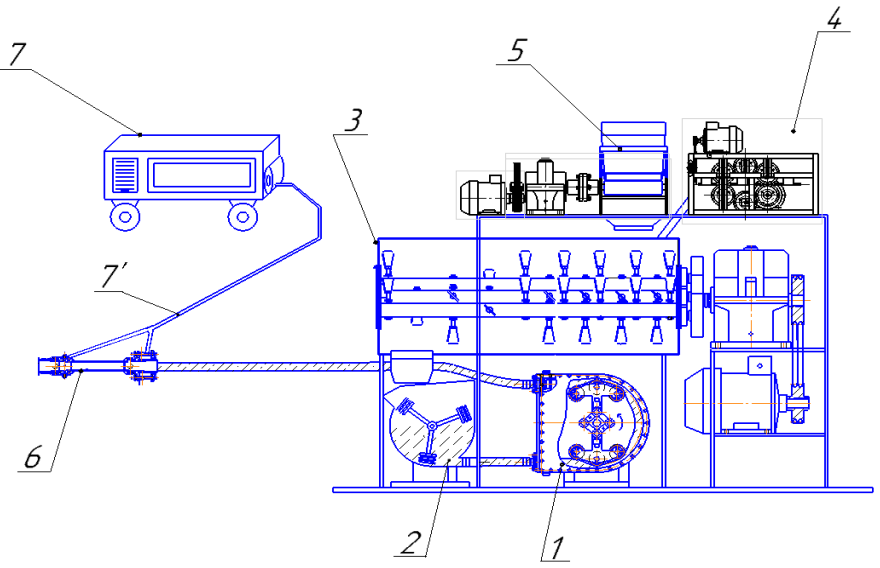

Figure 1 - Principal scheme of the small-sized technological set equipment with the use of universal hose concrete pump:

1 - universal non-piston hose concrete pump; 2 - receiving tank for concrete pump; 3 - long-time concrete mixer; 4 - automatic machine-cutter of synthetic fibers; 5 - ribbon feeder; 6 - a nozzle with a circular nozzle; $7,7^{\prime}$ - respectively compressor installation and hoses from the compressor to the nozzle

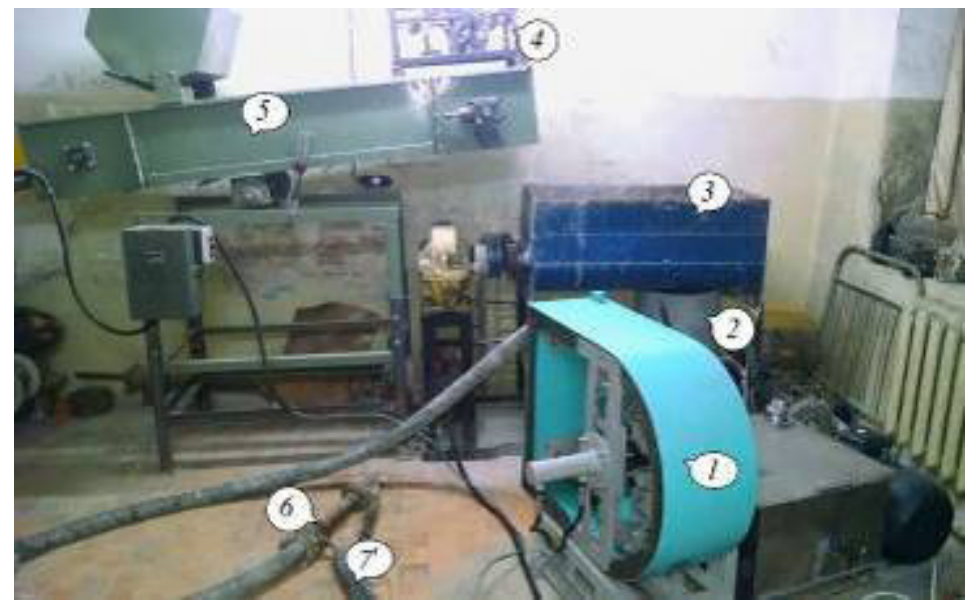

Figure 2 - Small-sized technological set equipment for carrying out a gunite work by wet method:

1 - universal non-piston hose concrete pump; 2 - receiving tank for concrete pump;

3 - long-time concrete mixer; 4 - automatic machine-cutter of synthetic fibers; 5 - ribbon feeder; 6 - a nozzle with a circular nozzle; $7^{\prime}$ - hoses of compressed air supply from the compressor to the nozzle 
The universal hose concrete pump is used as a base machine in the technological kit. To determine its main operating parameters, the dependencies are proposed::

$$
\Pi_{\text {tech }}=3600 F_{\text {hose }} v_{a v} k_{1} k_{2} k_{3}
$$

where $F_{\text {hose }}-$ cross-sectional area of the hose in the concrete pump housing, $\mathrm{m}^{2}$;

$v_{a v}$ - average speed of the concrete mixture through a flexible hose, $\mathrm{m} / \mathrm{s}$;

$k_{1}$ - coefficient that takes into account the gradual buildup of the force created by the pinch rollers of the rotor when compressing the outside of the hose in the pump casing;

$k_{2}$ - coefficient that takes into account the reliability of the hose in the pump casing, taking into account the ultimate stress state;

$k_{3}$ - coefficient that takes into account the conditions for the mixture to be delivered by a concrete pump via a flexible hose, taking into account the presence of its reverse currents:

- the power consumed for the process of transporting the concrete mixture to the nozzle shaft can be determined by the dependence:

$$
\begin{aligned}
& P_{g}=\frac{3.45 \cdot\left(G_{b s u m} \cdot k_{t r}+F_{p r u t} \frac{k_{t r . k o c h}}{r_{r o l}}\right) n \cdot R_{s r}}{1000 \cdot 30 \eta_{b n}}+ \\
& +\frac{S_{s h l} \cdot \Delta p \cdot v_{s r} \cdot k_{d l}}{1000 \eta_{g}}
\end{aligned}
$$

where $G_{b s u m}$ - the weight of the concrete mixture, which is under the influence of clamping rollers, $\mathrm{H}$; $k_{t r}$ - the coefficient of friction that occurs as a result of the wall effect between the inner wall of the flexible hose and the concrete mixture in the course of its movement;

$F_{\text {prut }}$ - the force of pressing the rollers to the outer surface of the flexible hose in the working space of the pump, $\mathrm{H}$;

$k_{t r k \text { koch }}-$ friction coefficient of rolling of rollers on the surface of the hose, $\mathrm{m}$;

$r_{r o l}$ - roller radius;

$n$ - rotor speed, $\min ^{-1}$;

$R_{s r}$ - average value of the distance between the rotor axis and the end face of the roller;

$\eta_{b n}$ - coefficient of efficiency of the concrete pump;

$\Delta p$ - pressure drop at the ends of the transport pipeline, $\mathrm{Pa}$;

$k_{d l}$ - coefficient taking into account the length of the transport pipeline;

$\eta_{g}$ - hydraulic losses in the transport pipeline;

- the suction pressure of the concrete mixture from the hopper of the concrete pump is determined by the following dependence:

$$
p_{v s}=\rho_{0} \cdot g \cdot H_{\text {sum }}+p_{a t}-\left(1+\varsigma_{\Sigma}\right) \rho_{0} \frac{v_{\text {sum }}^{2}}{2},
$$

where $H_{\text {sum }}$ - height of the concrete mix in the bunker, $\mathrm{m}$;

$p_{a t}-$ atmospheric pressure, $\mathrm{Pa}$;
$\varsigma_{\Sigma}-$ total loss of pressure when sucking a concrete mixture;

$v_{\text {sum }}$ - speed of the mixture through the inlet, $\mathrm{m} / \mathrm{s}$,

- the pressure which creates a universal hose concrete pump at injection of a concrete mixture to a nozzle shaker is defined as [9]:

$p_{n L}=\frac{4 \cdot m \cdot \omega^{2} \cdot R_{r} \cdot \varphi \cdot f}{\pi\left(D_{s h l}-2 \delta_{s h l}\right)^{2}}+\lambda \cdot \frac{L}{d_{t r}} \cdot \rho_{0} \cdot \frac{v_{s r}^{2}}{2}$,

where $m$ - mass of the rotor that overlaps the flexible hose in the pump housing;

$\omega$ - angular speed of the rotor of the concrete pump;

$R_{r}$ - the radius of the rotor of the concrete pump on the end of the roller;

$\varphi-$ zone of working process of injection of concrete mix, rad;

$f$ - coefficient of friction of the concrete mixture on the inner wall of the working hose in the pump body;

$D_{s h l}$ - outer diameter of the flexible hose;

$\delta_{\text {shl }}$ - hose wall thickness;

$\lambda$ - coefficient of resistance of the concrete mix along the pipeline;

$L$ - the length of the pipeline on which the concrete mixture is transported;

$d_{t r}$ - internal diameter of the transport pipeline;

$\rho_{0}-$ average density of concrete mix;

$v_{s r}$ - the average speed with which the concrete mixture is transported.

Using the aforementioned set of equipment, the concrete surface was wetted by means of wet gunitework.

For the vertical surface gunite, the following concrete mixture composition was used for $1 \mathrm{~m}^{3}$ : cement $-363 \mathrm{~kg}$, sand $-1107 \mathrm{~kg}$, rubble $-711 \mathrm{~kg}$, water 183 1, plasticizer Sikaplast 520 in volume of $1.5 \%$.

With the small-sized technological set equipment help, the concrete mixture, which was prepared in a long-time concrete mixer, was applied to the stand surface using a nozzle. In this case, the surface was concreted gradually when applying the concrete mixture to the layers. Each subsequent layer was applied after the previous hardening of the previous layer. Generally, the thickness of the layer on the cracked surface is $\delta=30 \ldots 40 \mathrm{~mm}$ (Fig. 3).

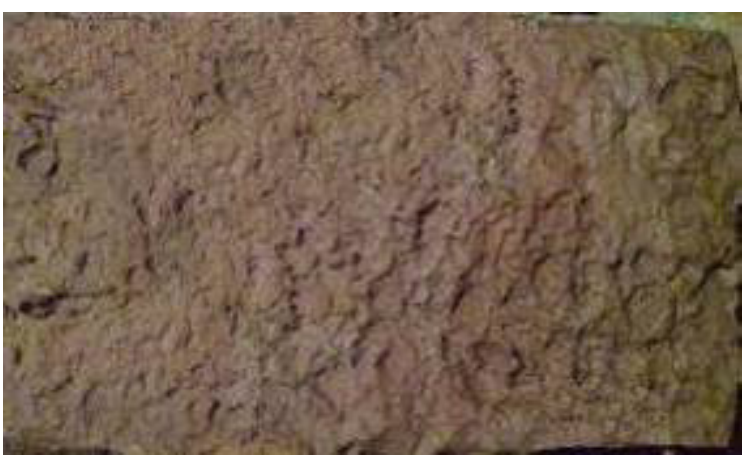

Figure 3 - The stand surface which was concreted by wet gunite method 
After 28 days of concrete mixture deposited layer solidification in the natural environment, it was tested for strength using the concrete strength meter Beton Pro CONTROL, which is presented in Fig. 4.

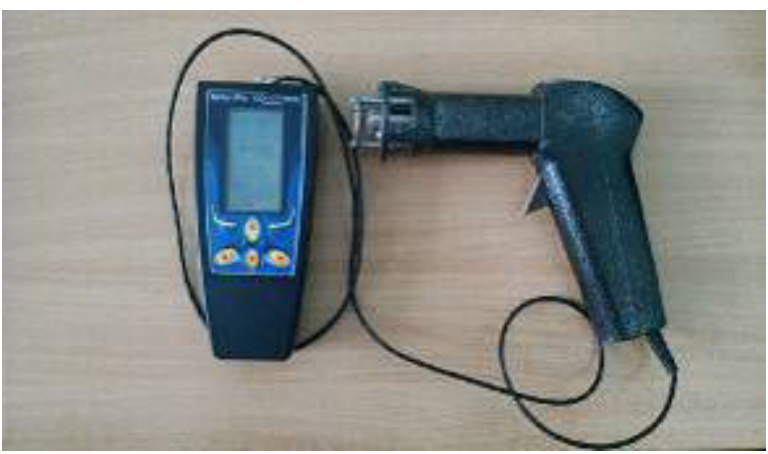

Figure 4 - Beton Pro CONTROL device for measuring concrete strength

Fig. 5 shows the concrete surface, which is wetted by wet cracking, and tested for compressive strength using the device shown in Fig. 4. The strength of the gunite concrete was determined at different points of the concrete surface.

The obtained test results are listed in Table 1.

The average value of the obtained concrete strength indicators with the device help is $47.7 \mathrm{MPa}$. Spread of data in Table 1 is $15 \%$. This testifies to the formation of a homogeneous gunite concrete structure.

Thus, the results of the conducted research showed that when working universal piston hose concrete pump to the nozzle with a ring nozzle on the hose to monounsaturated concrete mixture. This is evidenced by the lack of its bundle in the process of transportation. The stability of the operating conditions of the technological package, offered with the universal hose concrete pump, is confirmed.

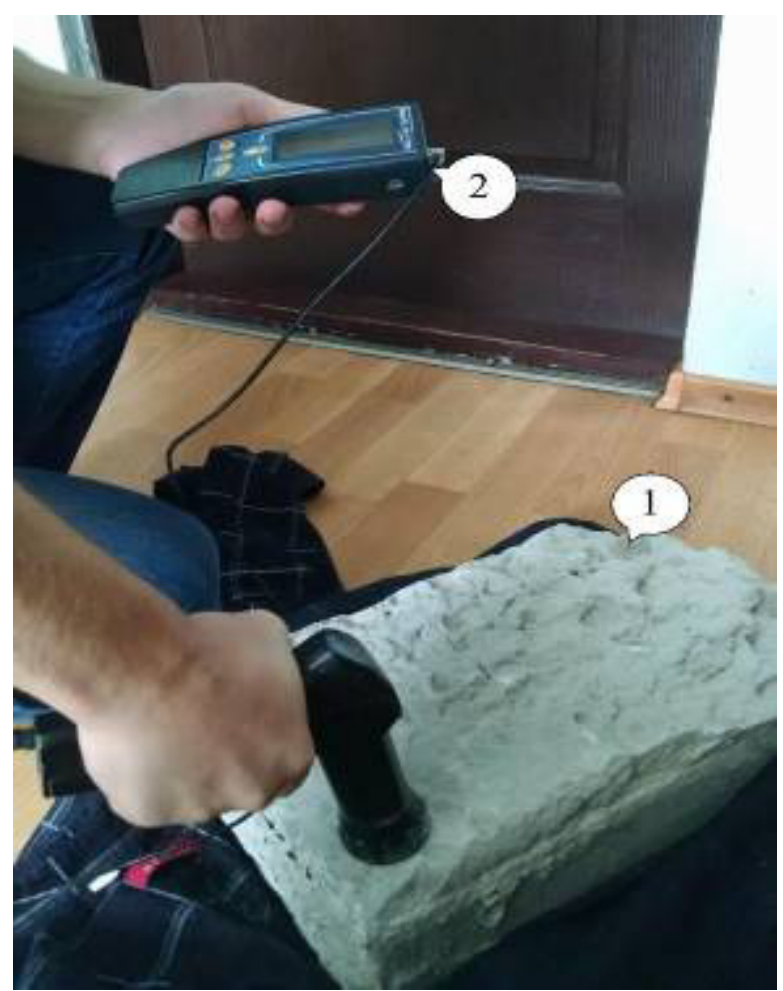

Figure 5 - The process of gunite concrete strength checking using the «Beton Pro Control» device:

1 - an example of a concrete surface gunited by wet method;

2 - Beton Pro CONTROL device for measuring concrete strength

Table 1 - Pressure concrete strength to compression

\begin{tabular}{|l|r|r|r|r|r|r|r|r|r|r|}
\hline $\begin{array}{l}\text { Metering num- } \\
\text { ber }\end{array}$ & $\mathrm{f}_{\text {com1 }}$ & $\mathrm{f}_{\text {com } 2}$ & $\mathrm{f}_{\text {com3 }}$ & $\mathrm{f}_{\text {com4 }}$ & $\mathrm{f}_{\text {com5 }}$ & $\mathrm{f}_{\text {com6 }}$ & $\mathrm{f}_{\text {com7 }}$ & $\mathrm{f}_{\text {com8 }}$ & $\mathrm{f}_{\text {com79 }}$ & $\mathrm{f}_{\text {com av }}$ \\
\hline $\begin{array}{l}\text { Strength com- } \\
\text { pressine val- } \\
\text { ues, MPa }\end{array}$ & 46.7 & 52.5 & 54.8 & 42.9 & 51.5 & 43.9 & 41.4 & 40.8 & 54.5 & 47.7 \\
\hline
\end{tabular}

\section{Conclusions}

1. The efficiency of a small-sized technological set equipment with a universal, non-porous hose concrete pump is shown.

2. Operating stability conditions confirmation of the technological kit with the hose concrete pump that is proposed for the test of the gunite concrete obtained on compression: the difference of the compressive strength results does not exceed $15 \%$. 


\section{References}

1. Moran, S. (2016). Process plant layout. Oxford: Butterworth-Heinemann.

2. Klespitz, J. \& Kovács, L. (2014). Peristaltic pumps - a review on working and control possibilities. IEEE 12th International Symposium on Applied Machine Intelligence and Informatics (SAMI 2014)/ Herl'any, Slovakia. http://real.mtak.hu/27727/1/37_sami2014.pdf.

3. Valigi, M.C. \& Gasperini, I. (2007). Planetary vertical concrete mixers: Simulation and predicting useful life in steady states and in perturbed conditions. Simulation Modelling Practice and Theory, 10-15, 1211-1223.

4. Henikl, J., Kemmetmiller, W. \& Kugi, A. (2016). Estimation and control of the tool center point of a mobile concrete pump. Automation in Construction, 61, 112-123.

5. Ємельянова, I.А., Задорожний, А.О., Гузенко, С.О. $\&$ Мєлєнцов, М.О. (2011). Двопориневий розчинобетононасос для будівельного майданчика: монографія. Харків: Вид-во Тимченко А.М.

6. Смельянова, I.А., Аніщенко, А.І., Євель, С.М., Блажко, В.В., Доброходова, О.В. \& Мєлєнцов, Н.О. (2012). Бетонозмішувачі, ще працюють у каскадному режимі: монографія. Харків: Team Publish Group.

7. Смельянова, I.А., Задорожний, А.О., Клименко, М.В. \& Чайка, Д.О. (2016). Універсальний безпориневий бетононасос. Патент України 112585. Київ: Державне патентне відомство України.

8. Emeljanova, I., Blazhko, V., Shatohin, V., Chayka, D. $\&$ Kobanets, D. (2017). Features of creation of universal technological sets of the small-sized equipment for conditions of a building. Науковий вісник будівництва (Scientific Bulletin of Civil Engineering), 4(90), 136-145.

9. Чайка, Д.О. (2018). Дослідження можливостей транспортування бетонної суміші універсальним шланговим бетононасосом. Вчені записки ТНУ імені B.I. Вернадського. Серія: технічні науки, 29(68), 25-31. 